\title{
MINHA CASA, MINHA VIDA PROGRAM AND ITS SPATIAL DISTRIBUTION IN RIO DE JANEIRO STATE
}

\author{
MINHA CASA, PROGRAMA MINHA VIDA E SUA DISTRIBUIÇÃO ESPACIAL NO ESTADO DO RIO DE JANEIRO
}

\begin{abstract}
The theme of this work focuses on some significant aspects of the housing problem in Brazil: the lack of housing, the quality of households, and the spatial distribution of buildings. These issues play a relevant role in the urbanization of the country and, in particular, in the state of Rio de Janeiro. In 2009, Minha Casa, Minha Vida program opened up a perspective in the housing sector. Created to help supply the housing deficit, this program stood out in the amount of investments and constructions as well as in advances related to the housing social perspective, since it intended to meet lower income population demands. This study aimed to analyze whether there was an increase in socio-spatial segregation in Rio de Janeiro state due to income range and a concentration of housing units within income ranges that include people with higher purchasing power. This work's methodology included analysis of quantitative and cartographic data coming from Brazilian government, study of bibliography on housing in Brazil, as well as preparation and analysis of maps based on spatial data.
\end{abstract}

Keywords: Rio de Janeiro state. Socio-spatial segregation. Minha Casa, Minha Vida program.

\section{RESUMO}

O presente artigo traz como tema aspectos significativos da problemática habitacional brasileira. A falta de moradias, sua qualidade e distribuição espacial são questões relevantes na urbanização do país e, em especial, no Estado do Rio de Janeiro. Nesse sentido, a partir de 2009 um novo ponto de inflexão se faz presente, o "Programa Minha Casa, Minha Vida" (PMCMV) foi criado de forma a dar subsídios a solvência do déficit habitacional brasileiro, se destacando pelos grandes subsídios orçamentários, do grande volume de construções e avanços na perspectiva social: o Programa buscava atender as faixas de renda mais baixas. Assim, o objetivo deste trabalho é verificar através da análise dos dados quantitativos e cartográficos um possível aumento da segregação socioespacial no estado do Rio de Janeiro em função da renda, além da concentração de unidades habitacionais nas faixas de renda com maior poder aquisitivo. A metodologia inclui análise de dados quantitativos e espaciais oficiais do Governo Federal, revisão da literatura ligada à habitação no Brasil e elaboração e análise de mapas a partir de dados espaciais.

Palavras-chave: Estado do Rio de Janeiro. Segregação Socioespacial. Programa Minha Casa Minha Vida.

\section{Dustavo Bezerra de Brito ${ }^{a}$ José Silvan Borborema Araújo ${ }^{\text {a }}$ (D) Glaucio José Marafon ${ }^{\text {a }}$ \\ ${ }^{a}$ Universidade do Estado do Rio de Janeiro (UERJ), Rio de Janeiro, RJ, Brasil}

DOI: $10.12957 /$ geouerj.2020.51548

Correpondência:

glauciomarafon@hotmail.com

Recebido em: 2 fev. 2020

Aceito em: 15 set. 2020 


\section{INTRODUCTION}

Many studies in Brazil have been analyzing the housing problem in the country. The lack of housing and the housing quality are central points to understand the current reality of urbanization. There is the consensus that the State has not been able to solve the problem and that the population portion most affected by urban problems is the low-income one. According to researchers, the highest housing deficit is in the social class of people within the low-income range.

In 2009, a new perspective emerged amid new regulations in the real estate sector. After the establishment of ambitious goals and the creation of the Ministry of Cities, it was launched a housing program: Minha Casa, Minha Vida (my house, my life). ${ }^{1}$ Created during president Luiz Inácio Lula da Silva second fouryear term and deepened in the government of president Dilma Rousseff, such program has offered elements to carry out new studies on public housing policies and on cities organization.

One can understand the relevance and representativeness of Minha Casa, Minha Vida program based on two factors. One factor is the incorporation of large investments, especially resources from the Union budget, and the number of buildings (in the program first phase, there were plans for one million new households). The other factor refers to advances in the social perspective of the program, because its aim was to meet particularly the demands of poorer urban populations.

According to Romagnoli (2015), the context of Minha Casa, Minha Vida program launching was an important moment in Brazil's economic history. The government considered it an "anti-cyclical" policy, a means to face the international financial crisis begun in 2008. In other words, such public policy emerged with the intention of boosting civil construction, creating jobs and stimulating the domestic market.

Nevertheless, certain problems in Minha Casa, Minha Vida program are remarkable. They include the lack of convergence between housing units' construction and a model useful to fight homelessness, the lack of an urban planning plan, and the lack of proper legalization of land owning. ${ }^{2}$ Other problems relate to patterns of real estate developments' urban insertion, for these latter would have reaffirmed a selective and precarious urbanization model in most cities, especially in metropolitan regions (ROLNIK et al., 2015, p. 127).

In Rio de Janeiro state, these contours became more visible. Ministry of Regional Development data from late 2018 lead to the following hypothesis. Although Minha Casa, Minha Vida program has brought innovations as for the granting of housing investments aiming at low-income populations and has expanded

\footnotetext{
${ }^{1}$ Minha Casa, Minha Vida program has reached its third phase but this study considers data that date back to December 31, 2018, when it ended Michel Temer government as president of Brazil.

${ }^{2}$ T. N.: There are examples of people who built a house in a public area with no legal right to own it. In this case, legalizing land owning is to grant such people the possession over the built area, that is to say, its property deed.
} 
the credit for real estate in the middle class, it did not consider the territory as a central aspect of a housing policy that intends to solve the right problems in this matter.

In this regard, this study is concerned with verifying a possible increase in socio-spatial segregation in Rio de Janeiro state due to income and the concentration of housing units in intermediate levels of population, which means, people of higher purchasing power (especially income ranges 2 and 3). It analyzes quantitative and cartographic data related to the state. The article contains three interconnected parts. The first part briefly discusses overall aspects of Minha Casa, Minha Vida program working and execution, considering that about ten years after its launch it has been the subject of numerous researches and surveys on housing in Brazil. This part shows the main features of the program. The second part focuses on the state of Rio de Janeiro. The analysis of cartographic material expands the data to portray particularities of Rio de Janeiro state. Final remarks associate the program as public policy with patterns identified in the analysis.

\section{Overall aspects of Minha Casa, Minha Vida program}

As a Brazilian housing public policy, it is remarkable the strong meaning that Minha Casa, Minha Vida program has when compared to similar policies in recent years. No matter the economic, territorial and social impact, it means a focal point in the history of housing in Brazil. In a practical sense, the program has repositioned the housing problem within Brazilian government agenda. Hervé $(2017$, p. 2) states it as "the most significant program in the country's housing sector in the last thirty years".

Minha Casa, Minha Vida program was regulated by the law number 11.977 (July 7, 2009), after more than two decades of housing problem neglect by Brazilian government (save for singular actions with no structural changes) (BONDUKI, 2008). The law structured the program through an urban housing national plan (PNHU) and through a rural housing national plan (PNHR).

Regarding Minha Casa, Minha Vida program aims and investments, there were high expectations. In the first phase of the program, the plan was to build one million housing units within two years - a relatively short period. The amount invested summed up R\$ 34 billion, being R\$ 25.5 billion from the Union budget and R\$ 7.5 billion from FGTS fund. ${ }^{3}$ In addition, investments of $R \$ 1$ billion were planned for the urban infrastructure. It would come from Banco Nacional de Desenvolvimento Econômico e Social (Brazilian bank for the economic and social development).

In case of families whose monthly income amounted to up to three minimum wages, the goal of Minha Casa, Minha Vida program was to build 400,000 housing units with a monthly payment of $\mathrm{R} \$ 50$ - a sum seen as symbolic

\footnotetext{
${ }^{3}$ T. N.: FGTS is a security fund created to protect employees in case of unfairly dismissal. In an account opened in connection with the employment contract, the employers must deposit an amount of 8 per cent of each employee gross salary in the beginning of each month within the contract time length.
} 
then. As to families whose income ranged from three minimum wages to six minimum wages, the goal was to build 400,000 units as well, this time through PNHU housing program. As for families with income ranging from six minimum wages to ten minimum wages, the goal was to build 200,000 units with financing from FGTS fund. Farmers, in turn, would request financing according to their income (CARDOSO \& ARAGÃO, 2013 apud ANDRADE, 2012).

Still in this line of thought, it is important to analyze the figure 1, on the higher incidence of housing deficit in the country. This deficit is the sum of precarious housing components, family cohabitation, excessive expenses with rent, and too much densification (FUNDAÇÃO GETÚLIO VARGAS, 2018). The understanding of the problem becomes more complex when it comes to urban problems such as violence, inequality, deficient transportation, lack of electricity infrastructure, sanitation, etc.

Figure 1. Relative distribution of housing deficit by household income range - 2017. Source: Fundação Getúlio Vargas (2018)

Up to 1 minimum wage
More than 5 to 10 minimum wages $\quad$ More than 1 to 3 minimum wages 10 minimum wages

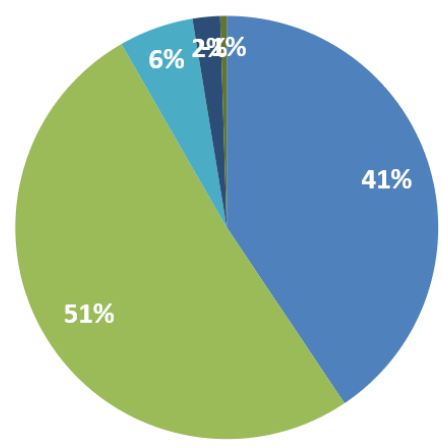

Regarding the distribution of the total housing deficit in income ranges, it is noticeable the emphasis on a population whose income is up to three minimum wages. Once added the income ranges, which varies from up to one minimum wage to one to three minimum wages, the result is 91.7 per cent of the whole deficit, that is to say, 7.1 million housing units. Therefore, Minha Casa, Minha Vida program adapted its aims in order to focus most of units' constructions on the population most affected by the deficit.

In this regard, where housing deficit falls mainly on the low-income population, the main guidelines predicted decrease in the housing deficit by 14 per cent - above all in municipalities where population is superior to 100,000 inhabitants - and boosting of the building sector - responsible for 5.7 per cent of Brazilian gross domestic product (ROMAGNOLI, 2012).

Phases 2 and 3 of Minha Casa, Minha Vida program (both started under Dilma Rousseff government) were expected to last three years, while the goal was to build two million housing units. At these stages, 60 per cent of the 
units would go to families with income of up to $R \$ 1,600$ - the lowest range; 30 per cent to families with income between $R \$ 1,600$ and $R \$ 3,100$ - the second range; finally, 10 per cent to families with income between $R \$ 3,100$ and $R \$ 5,000$ - the last range (see table 1). Therefore, the program has turned out to be implemented with three income ranges, instead of being based on the minimum wage amount as in its early days (RAMOS and NOIA, 2014).

Table 1. Housing hiring goals of Minha Casa, Minha Vida program. Data source: Brasil (2019) ${ }^{4}$

\begin{tabular}{lcc}
\hline \multicolumn{1}{c}{ INCOME } & UNITS & $\%$ \\
\hline Up to $R \$ 1,600$ & $1,200,000$ & 60 \\
$\mathrm{R} \$ 1,600$ to $\mathrm{R} \$ 3,100$ & 600,000 & 30 \\
$\mathrm{R} \$ 3.1000$ to $\mathrm{R} \$ 5,000$ & 200,000 & 10 \\
Total & $\mathbf{2 , 0 0 0 , 0 0 0}$ & $\mathbf{1 0 0}$ \\
\hline
\end{tabular}

In its second phase, Minha Casa, Minha Vida program had its investments enlarged. The forecast of funds reached “R\$ 125 billion, being R\$ 72.6 billion to subsidies and R\$ 53.1 billion to financing" (ANDRADE, 2012, p. 53). There were operational changes as well, one being Banco do Brasil taking part in the program in order to speed processes such as work contracting and monitoring as well as financing and transfer of resources. Besides, there were modifications in apartments' technical specifications so that to include the obligation of using ceramics on the floor of all rooms; and 3 per cent of the housing units would go to people with physical disabilities (whose houses requires adaptations such as wider doorways and larger bathrooms).

Despite Minha Casa, Minha Vida program amount of investments and its contours of assistance and income redistribution, it raises critical assessments in different sectors of society. Much of them address the excessive delay in the building works schedule and in the quality of housing buildings. There are even examples of contracted housing units that were not delivered. In addition, many units are given as finished while showing misaligned walls, holes in masonry, shoddy painting, non-standard sanitary ware drips and infiltrations, among other problems (ANDRADE, 2012, p. 56).

Some critics said that, although Minha Casa, Minha Vida program's goals aim to solve urban problems all over the country, their reach is limited. Arantes and Fix (2009) argue that the program has no device to encourage the reuse of old unoccupied properties, which would delimit the social function of the property. The building of most of contracted housing units starts from scratch. According to them, building from scratch is not necessarily the best way to tackle housing problems. Alternatives are able to repeat and adapt public policies that occur in other countries; above all, policies to create public funds for acquisition, expropriation and subsidized rental of housing units aimed at not only reducing housing deficit but also facing real estate speculation and urban network growth.

\footnotetext{
${ }^{4}$ Information from Secretary of Brazilian Government. Go to: <http://www.secretariadegoverno.gov.br/iniciativas/internacional/fsm/eixos/inclusao-social/minha-casaminha-vida> Access in 2019.
} 
In addition, there are no guidelines to encourage construction companies to promote the construction of buildings in smaller lots of central areas (already densely urbanized and with infrastructure) and no guidelines to requalification of buildings. These practices would be convergent to those proposed in Minha Casa, Minha Vida program.

Borges (2013) indicates that 97 per cent of Minha Casa, Minha Vida program's public funds go to the supply and direct production in private construction companies, leaving aside master plans' regulation. This might be a difficulty for municipalities when it comes to use instruments contained in the City Statute, which would turn the private initiative into protagonist.

According to Rolnik et al. (2015, p. 148), there are other ways to provide housing units than building them. Due to disarticulation between policy guidelines and PNH plan (Brazilian national housing plan), other housing solutions are inhibited, as it happens to the urbanization of precarious settlements and to the building in partnership with organizing entities. This situation would contribute to the phenomenon of socio-spatial segregation in cities; once more, with a tendency to build on lots that are cheaper and, consequently, away from the urban network. ${ }^{5}$ In this case, Minha Casa, Minha Vida program would ignore the urban problem, even if it considers the conditions abovementioned.

In 2010, Ermínia Maricato said in an interview that a program of such relevance to the housing sector should have ways of dealing with land ownership status in order to regulate speculation profits and to ensure property's social function. As she said, Minha Casa, Minha Vida program characterizes a regress as to the evolution already achieved and consolidated in Brazilian urban legislation.

In the state of Rio de Janeiro, this phenomenon shows significant contours. As the population majority lives in the metropolitan region, there is a strong tendency towards a metropolitan concentration. Therefore, considering numbers in table 2, it is not surprising the housing deficit standing out in the metropolitan region with almost 66 per cent, while in the countryside it reaches 34 per cent.

Table 1. Housing deficit in Rio de Janeiro state, 2015.

\begin{tabular}{lcc}
\hline \multicolumn{1}{c}{ SPECIFICATION } & HOUSING DEFICIT IN RIO DE JANEIRO STATE, 2015 \\
\hline & Total & \% in the state \\
\hline Rio de Janeiro metropolitan region & 304.083 & $66 \%$ \\
Rio de Janeiro countryside $^{6}$ & 155.977 & $34 \%$ \\
Total Rio de Janeiro state & 460.785 & $100 \%$ \\
\hline Data source: Brazilian Institute of Geography and Statistics & (2019), National Household Sample Survey (2019)
\end{tabular}

Considering this table numbers, Rio de Janeiro state has significant chances of posing the problems abovementioned. That is why it is necessary to assess the housing units' situation. Assessing it allows verifying

\footnotetext{
${ }^{5}$ The building of housing units in the outskirts helps to form fragmented and expensive cities, for it is necessary to set up new public equipment in such areas.

${ }^{6}$ Municipalities not included in Rio de Janeiro state's metropolitan region.
} 
the results of a public policy that was supposed to try to solve housing problems and that inversely may contribute to the segregation and social inequality due to the inability of cities organization instruments.

Besides, it is needed to emphasize that understanding the maps presented ahead requires to be aware of some Rio de Janeiro state characteristics; for instance, its political and administrative divisions as well as its spatial organization guiding elements. Marafon et al. (2011) study is recommended as a useful reading in the analysis of past and current socio-political aspects that mark the state regions.

Spatialization of Minha Casa, Minha vida program in the state of Rio de Janeiro

Given the dimension of Minha Casa, Minha vida program, which involves socioeconomic, political and cultural aspects, its spatialization and effectiveness require to pay attention to the deliverance of housing units in the territory of Rio de Janeiro state. Rio de Janeiro is in the southeast (figure 2). Its estimated population for 2019 was of 17,264,943 inhabitants (IBGE, 2019). Its housing deficit is significant, especially in the metropolitan region, although such expressiveness does not exempt other state regions from it.

Figure 2. Housing deficit in Rio de Janeiro state, 2015. Source: CEPERJ (2019)

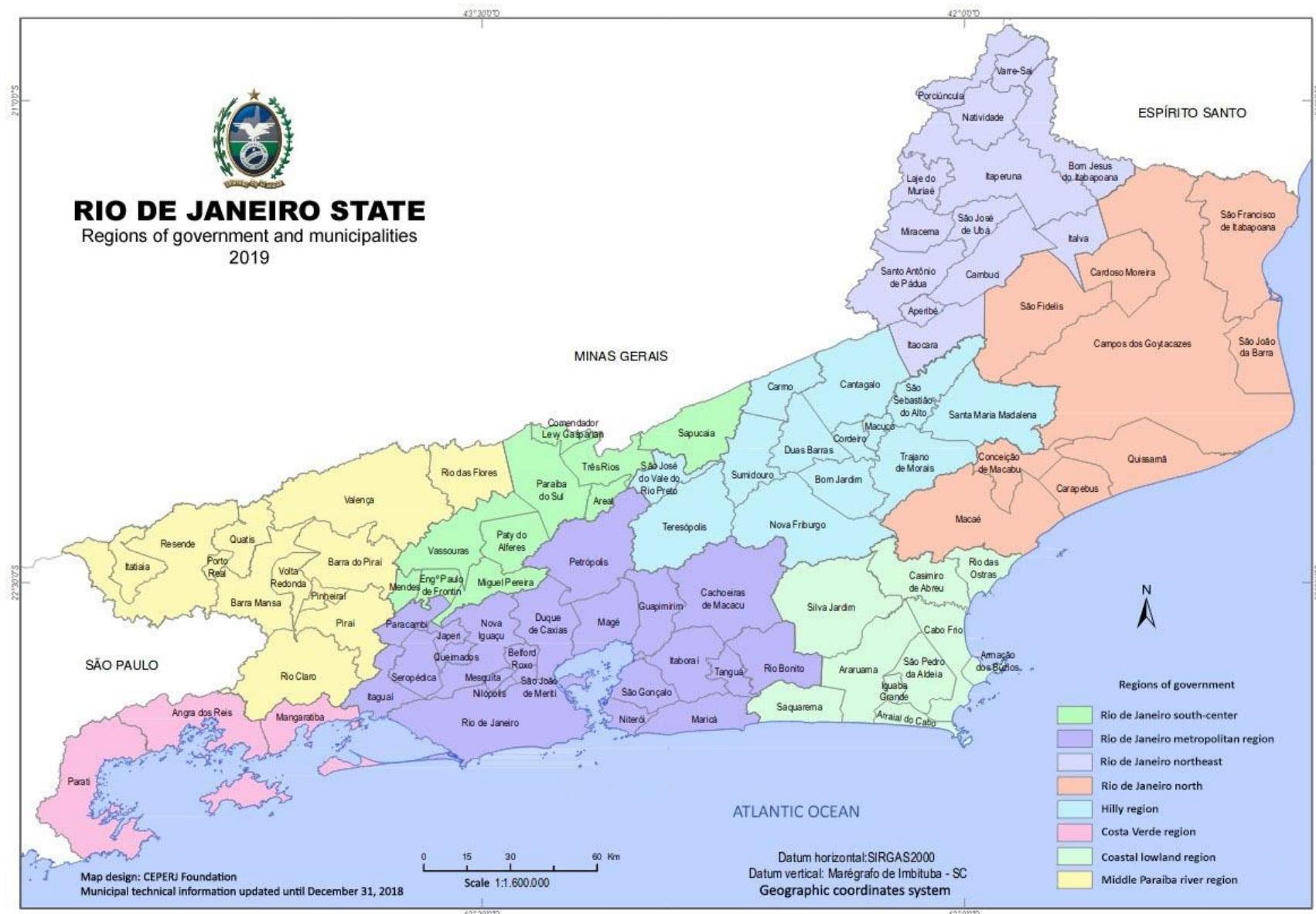


In this scenario, Minha Casa, Minha Vida program spatialization has covered all regions of Rio de Janeiro state, being distributed in the three income ranges. ${ }^{7}$ Contracted units deliverance in such ranges, however, occurred with greater significance in range 3, aimed to a social class with higher buying power. Nevertheless, income range 1 - related to families whose monthly income was up to 3 minimum wages (low income) had the lowest numbers of units (figure 3 ) when compared to the other income ranges.

Figure 3. Housing units contracted within income range 1. Data source: Ministry of Regional Development (2019)

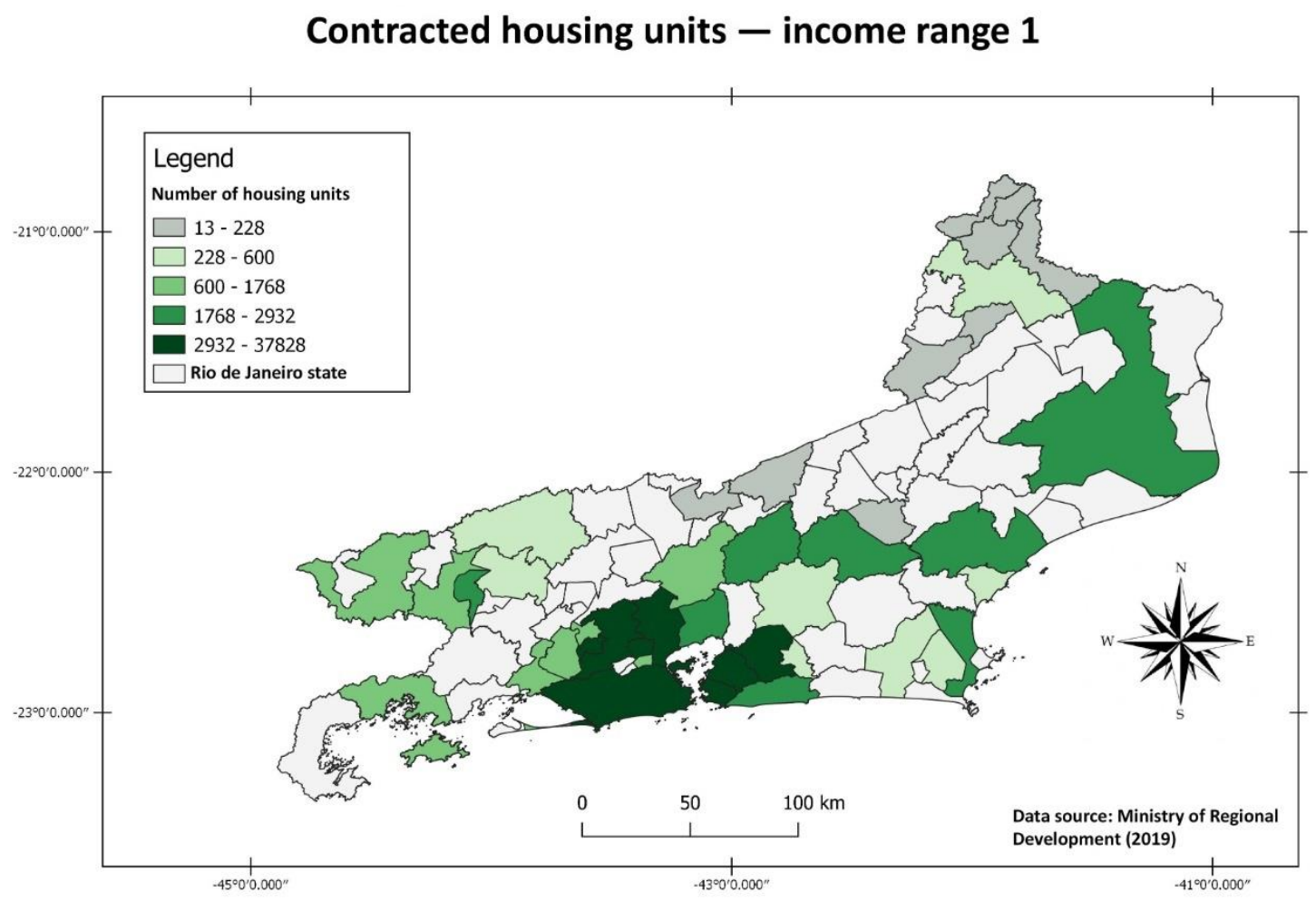

Figure 3 allows realizing that the spatialization in the contracting stage of Minha Casa, Minha Vida program covered all regions of Rio de Janeiro state, although it did not include many countryside municipalities. It is noticeable a higher demographic concentration in the metropolitan region, where the number of contracted housing units was significant. It varied from 2,932 to 37,828 , covering the capital and municipalities of Duque de Caxias, Belford Roxo, Nova Iguaçu, Queimados, Niterói, São Gonçalo, and Itaboraí. In addition, to some municipalities that polarize other state administrative regions, the delivered contracted units were within income range 1. In municipalities such as Campos dos Goytacazes, Teresópolis, Nova Friburgo, Macaé, Cabo Frio, Maricá, Magé, and Volta Redonda, the number of contracted units varied between 1,768 and 2,932. Other regions did not have a significant amount of contracted units within income range 1.

\footnotetext{
${ }^{7}$ In addition to income ranges 1, 2 and 3, Minha Casa, Minha Vida program met the needs of an intermediate income range: up to 1 and a half minimum wage. This study's analysis do not focus on such intermediate range because it did not result in significant amounts of units contracted, completed and delivered; that is to say, it does not affect the analysis of the program in the state of Rio de Janeiro.
} 
Therefore, the largest number of housing units in range 1 is in the above-mentioned municipalities, which means that much of the state's territory remained uncovered. It is important to highlight that this trend of spatialization within range 1 follows the trend of other stages of Minha Casa, Minha Vida program, although it presents a deficit in the finishing stage and in the deliverance of housing units (figures 4 and 5 ).

Figure 4. Housing units completed within income range 1. Data source: Ministry of Regional Development (2019)

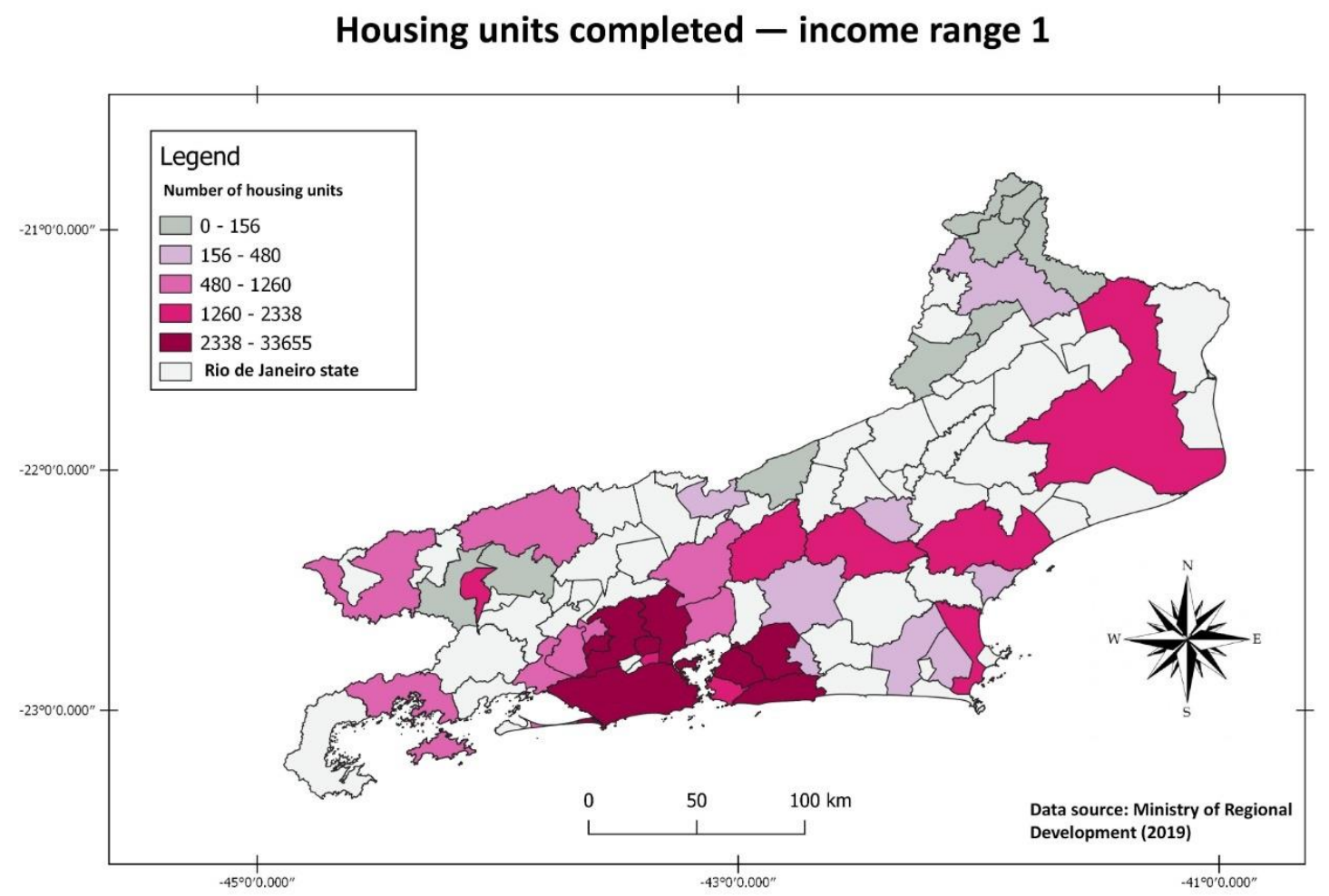

Finished housing units, of course, turn out to be focused on where more units contracted were; but it is noticeable that municipalities such as Nova Friburgo, in the hilly region, were able to deliver a number of units higher than the average at this stage of Minha Casa, Minha Vida program. In Nova Friburgo, there were between 1,260 and 2,338 units completed, and these numbers enter the class between 2,128 and 32,702 units delivered (figure 5). Thus, Nova Friburgo may have delivered all the housing units contracted. It is worth remembering that a climate tragedy hit the municipality in 2011, so that many people lost their properties because of floods. 
Figure 5. Housing units delivered within income range 1. Data source: Ministry of Regional Development (2019)

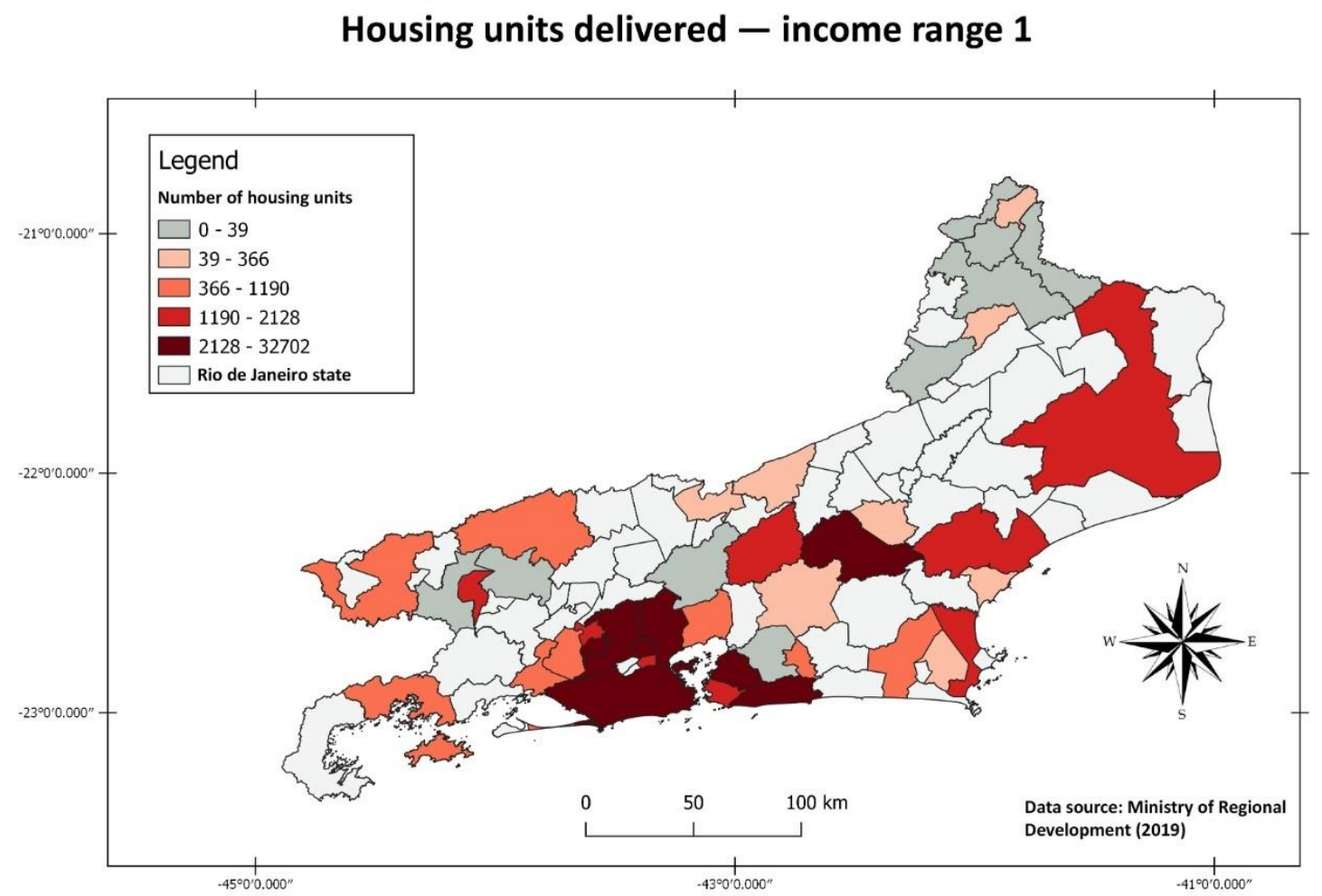

The analysis of the spatialization of delivered housing units in income range 1 confirms a selective process. In fact, as the larger population contingent is in the metropolitan region, the housing deficit in such region is higher, which justifies its greater concentration of housing units. Nevertheless, municipalities that appeared with contracted units lost their participation insofar as Minha Casa, Minha Vida program progressed, because they could not deliver those units.

That said, it is noticeable that housing units within income range 1 have been spatially concentrated, with a lower number of units contracted, finished, and delivered. One should highlight that families included in income range 1 are the most vulnerable when it comes to the housing deficit and to the focus of Minha Casa, Minha Vida program.

When housing units aimed at income range 2 (families whose monthly earning are between 3 minimum wages to 6 minimum wages) are taken into account, they show more spatialization, for they appear expressively in all state regions and in all modalities (contracted, finished and delivered) (figure 6). 
Figure 6. Housing units contracted within income range 2. Data source: Ministry of Regional Development (2019)

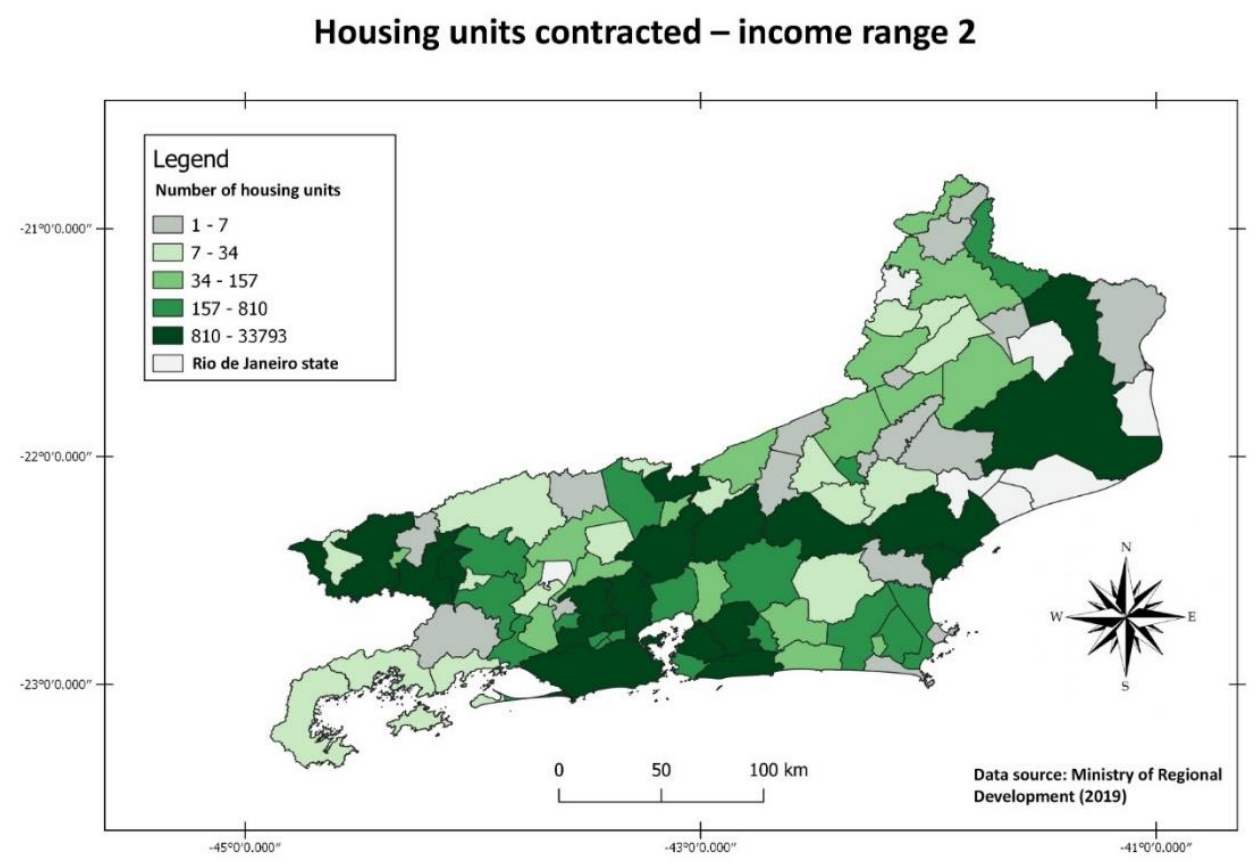

In addition to municipalities mentioned in the case of income range 1, the municipalities of Petrópolis, Rio das Ostras, Três Rios, Barra Mansa, and Resende have a higher number of housing units. They participate with higher numbers of contracted units, which varied between 810 and 33,793.

Income range 2 does not show relevant variations when compared to range 1 (figure 7), although other income ranges showed a slight decrease in the number of units constructions.

Figure 7. Housing units finished within income range 2. Data source: Ministry of Regional Development (2019)

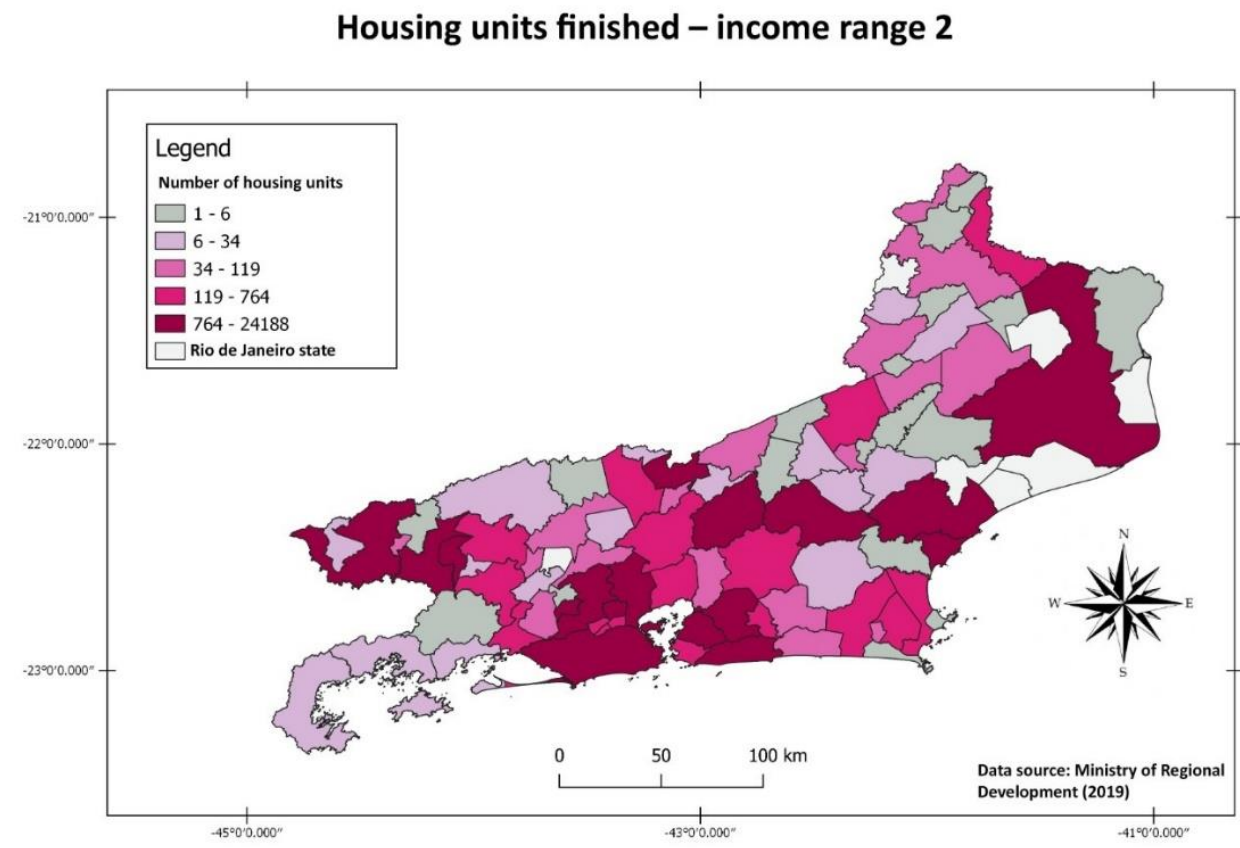


In general, there was no interruption between the stages of housing units' hiring and finishing related to income range 2 . Housing units were finished even in municipalities that presented contracted units. Therefore, there were no relevant losses in such income range. The same trend prevailed in the final stage of the program, with the deliverance of housing units (figure 8). All municipalities that had units contracted were able to deliver them, without interrupting the program phases.

Figure 8. Housing units delivered within income range 2. Data source: Ministry of Regional Development (2019)

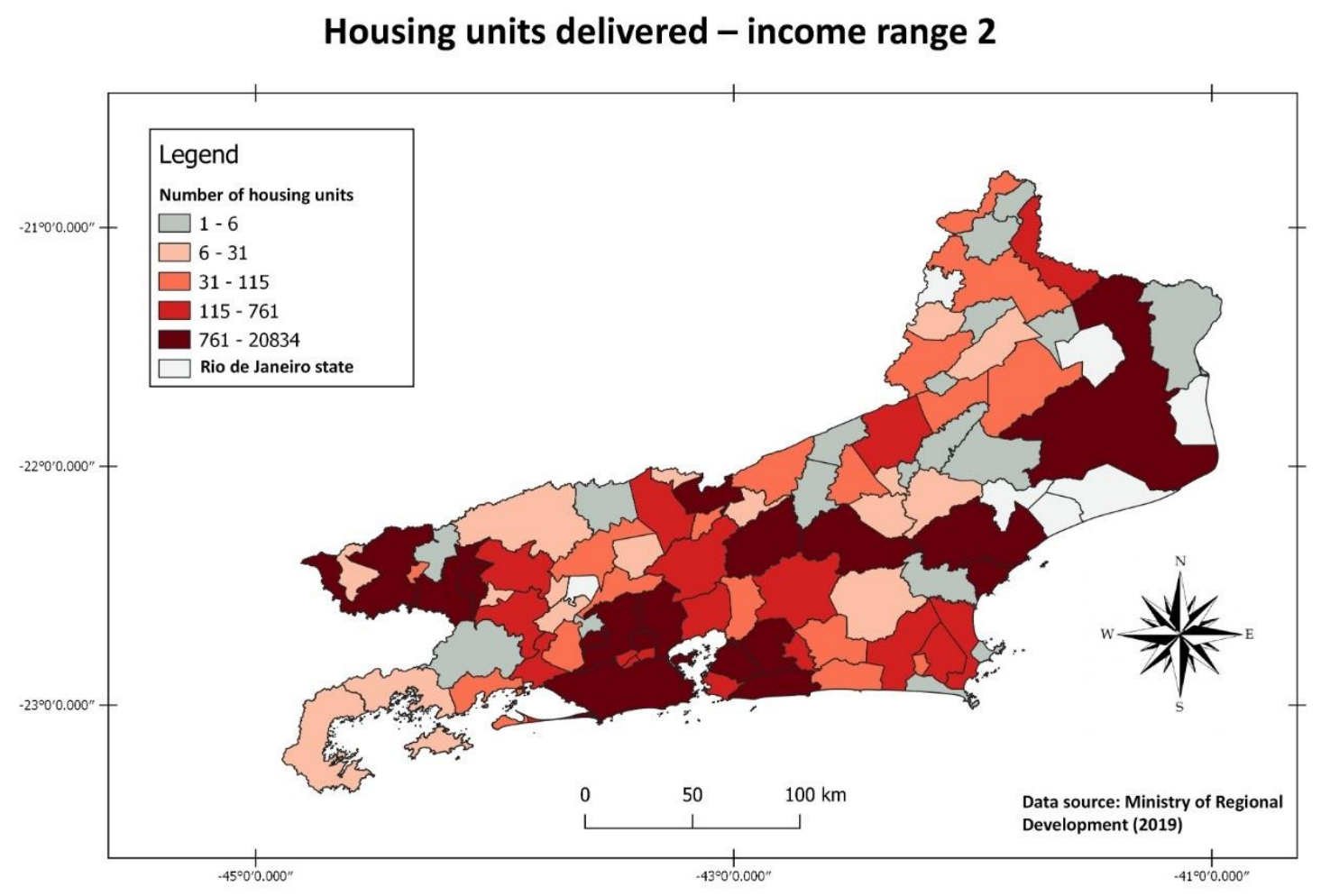

Thus, it is possible to notice that, within income range 2, Minha Casa, Minha Vida program was able to fulfill its phases significantly. It was delivered more than 50 per cent of housing units contracted in each area of Rio de Janeiro state. It is noteworthy that, in general, income range 2 shows a higher number of units when compared to range 1 .

In the case of income range 3 (covering families whose income is from six minimum wages to ten minimum wages), its spatialization was inferior to that of ranges 1 and 2 . It was higher than that of the range 1 , though (figure 9). 
Figure 9. Housing units contracted within income range 3. Data source: Ministry of Regional Development (2019)

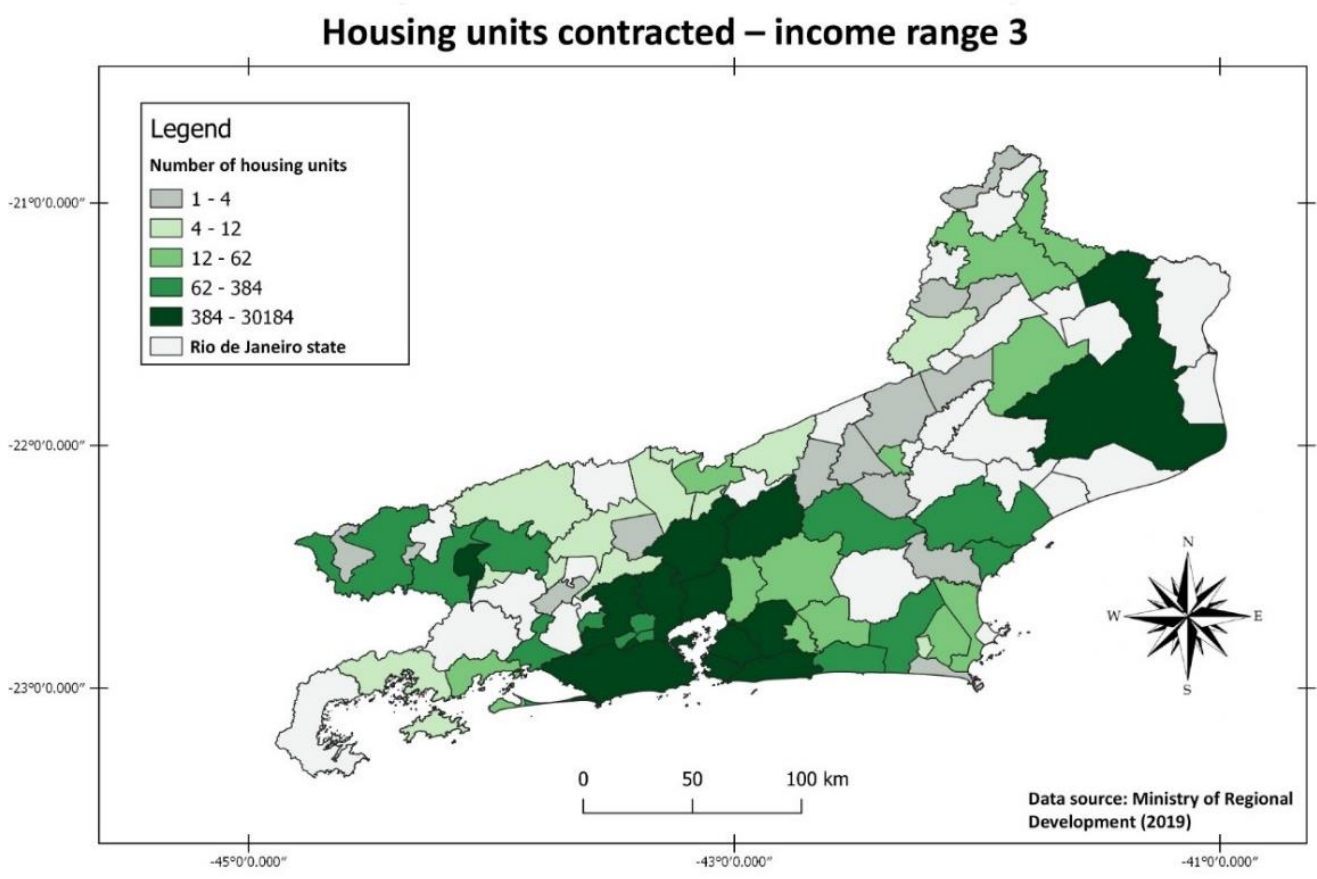

As a spatialization trend for all income ranges, the highest number of housing units in all stages is in Rio de Janeiro metropolitan region. It covers all state regions, but it is less dense in the countryside. This uniform spatialization in the state territory repeats itself in other stages of Minha Casa, Minha Vida program. It is the case of finished housing units (figure 10). There was no significant loss as for finished housing units in relation to the contracted ones.

Figure 10. Housing units finished within income range 3. Data source: Ministry of Regional Development (2019)

\section{Housing units finished - income range 3}

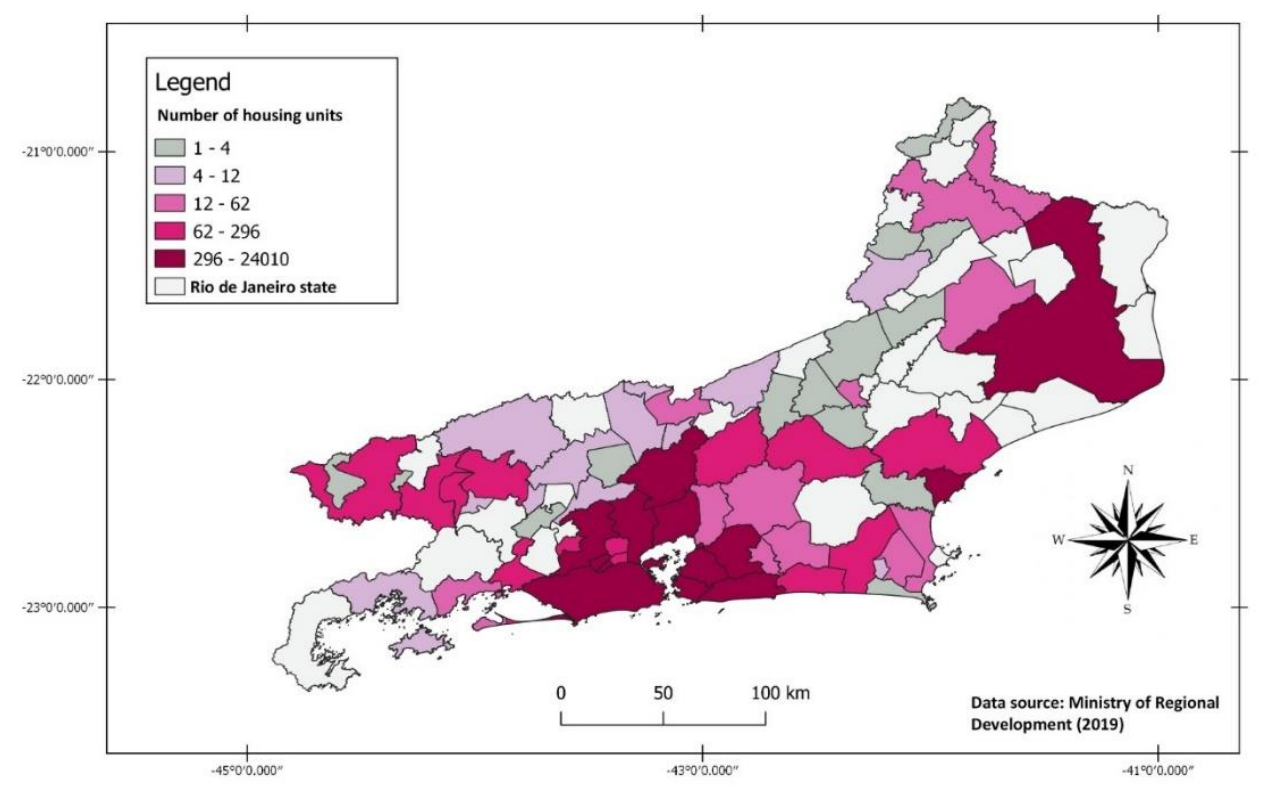


As said, at the stage of finishing, the spatialization of Minha Casa, Minha Vida program by municipalities remained the same. No relevant losses were noticed as for finished housing units. In fact, within income range 3 , the program managed to maintain the largest number of units. Although significant, the loss in the stage of units' deliverance was generally smaller than in contracting and finishing stages, as shown in figure 11.

Figure 11. Housing units delivered within income range 3. Data source: Ministry of Regional Development (2019)

\section{Housing units delivered - income range 3}

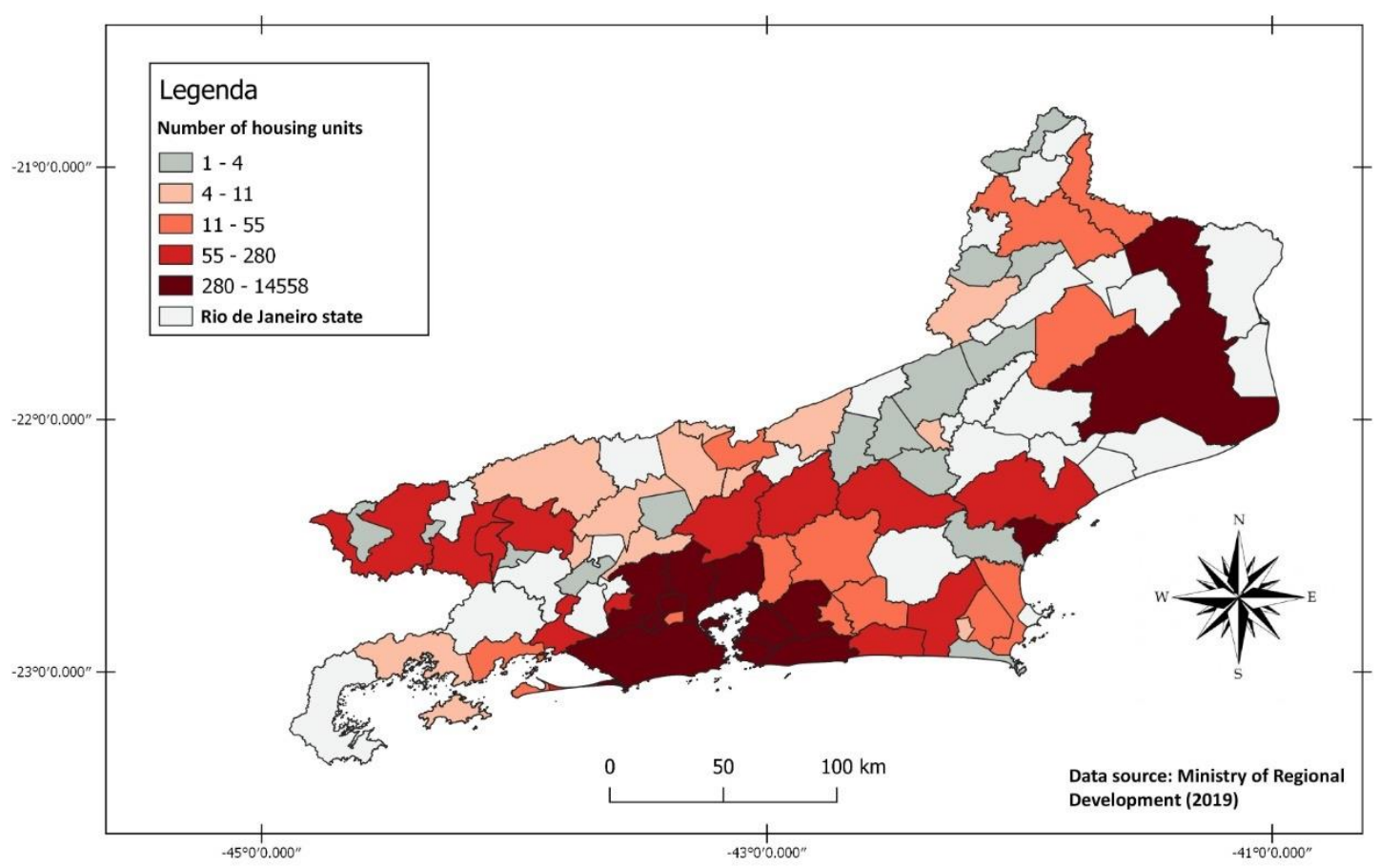

Given these observations, one may reaffirm that there was more continuity in income range 3 regarding contracted, finished and delivered housing units. Most was located in municipalities of Rio de Janeiro metropolitan region and in Campos dos Goytacazes and Rio das Ostras municipalities. The number of units delivered ranged from 280 to 14,558. The municipalities of Resende, Barra Mansa, Volta Redonda, Barra do Piraí, Itaguaí, Queimados, Petrópolis, Teresópolis, Nova Friburgo, Macaé, Maricá and Araruama participated with a number of housing units deliverance between 55 and 280 .

This scenario allows pointing out the selective characteristic of Minha Casa, Minha Vida program. After all, housing units within income ranges 2 and 3 had more privilege when compared to those of range 1 . Privileges included, for example, choosing best locations within cities - that is to say, areas with no serious risks -, infrastructure and units modality (which may be apartment and house).

As for income range 1, which received more government investments and covered the majority of the population with housing deficit, real estate sector's interests seem to have been more elevated. There was no 
previous study on conditions of risk. Besides, it was not respected the origin of the people who would be covered by the program, as in the case of families from Terra Nova, in Nova Friburgo. After loosing their properties due to a climate tragedy, families of different origins had to be relocated to an area farther from their origin place without guarantees of quality of life because it lacks basic urban services.

That said, as a program to favor the social class most in need of housing and facing housing deficit problem in Rio de Janeiro state, Minha Casa, Minha Vida program has left gaps, especially when one analyzes maps for the program's three phases within income range 1 . Thus, to be implemented uniformly, it is necessary that public housing policies consider not only the quality factor, but also the diversity of areas and interests marking Rio de Janeiro state territory.

\section{FINAL REMARKS}

By analyzing housing public policies in Brazil over the last decades, this study has made possible to understand that Minha Casa, Minha Vida program played a relevant role in the housing sector within Brazilian government. It not only repositioned housing problems in the government agenda, but also helped to boost the economy, which had the effect of slowing government's reaction to the economic crisis that hit other countries in late 2000s.

Given the housing units construction estimates in Minha Casa, Minha Vida program for the three stages this study focused on (three million between 2011 and 2018, encompassing the government of Luiz Inácio Lula da Silva and of Michel Temer), most of them was supposed to benefit population with an income of up to 1 minimum wage. After all, such income range covers a huge number of people in Brazil and in Rio de Janeiro state, where housing deficit is a severe problem. Nevertheless, actions of the program to minimize the problem have left gaps, especially in the social class most affected by homelessness, which is the one included in income range 1.

In fact, in the state of Rio de Janeiro, income range 1 stood out in posing problems in the three stages of implementation of Minha Casa, Minha Vida program (hiring, finishing, and deliverance) and problems in the location of lots. Commonly, this latter was far away from cities central areas and from areas where people had already established themselves to live. Besides, problems relate to the lack of services in the housing developments surrounds, which forces population to look for them in other areas of the city. In a word, the program did not help the social group most in need of housing to fulfill the aspiration of owning a house or an apartment to live a more comfortable life.

On the other hand, income ranges 2 and 3 had more privileges in several aspects, varying from location to housing modality (house or apartment). It can be said the number of units contracted, finished, and 
delivered within these ranges were significantly relevant when compared to the number within income range 1 , which is the target of Minha Casa, Minha Vida program.

Of course, despite Minha Casa, Minha Vida program flaws, it did not fail in guaranteeing housing for millions of Brazilians, especially in Rio de Janeiro. In this state, a considerable number of people managed to own a house through the program.

\section{REFERENCES}

ANDRADE, Gabriel Vieira Marx. Políticas Habitacionais Brasileiras: Uma Avaliação do Programa Minha Casa, Minha Vida em suas duas edições (Dissertação de Mestrado). Rio de Janeiro, 2012.

ARANTES, Pedro Fiori; FIX, Mariana. Como o governo Lula pretende resolver o problema da habitação. Caros Amigos, p. 1-25, 2009. Disponível em: https://xa.yimg.com/kq/groups/14917735/451095191/name/Pacote_Pedro_Mariana_Final_COMPLETO.pdf Acesso em 2019.

BONDUKI, N. Política habitacional e inclusão social no Brasil: revisão história e evolução no Governo Lula. Revista Eletrônica de Arquitetura e Urbanismo, São Paulo, n.1, p.70-104, 2008.

BORGES, Raphael Melo. Análise de desempenho térmico e acústico de unidades habitacionais construídas no conjunto habitacional Benjamin José Cardoso em Viçosa-MG. 149 p. Dissertação (Mestrado em Engenharia Civil) - Universidade Federal de Viçosa, Viçosa MG, 2013.

Fundação CEPERJ - Centro Estadual de Estatísticas, Pesquisas e Formação de Servidores Públicos do Rio de Janeiro. Cartografia fluminense, 2019. Disponível em: <http://www.ceperj.rj.gov.br/>. Acesso em 2019.

Fundação Getúlio Vargas. Análise das necessidades habitacionais e suas tendências para os próximos 10 anos. Rio de Janeiro, 2018.

HERVÉ, Thery. Novas Paisagens Urbanas do Programa Minha Casa, Minha Vida. Mercator - Revista de Geografia da UFC., Fortaleza, v. 16, n. 1, 2017.

IBGE - Instituto Brasileiro de Geografia e Estatística. População do estado do Rio de Janeiro. Disponível em: https://cidades.ibge.gov.br/brasil/rj/panorama Acesso em: 24/09/2019.

MARAFON, G. J. (orgs.). Geografia do Estado do Rio de Janeiro: Da compreensão do passado aos desafios do presente. Rio de Janeiro: Gramma, 2011. $161 \mathrm{p}$.

MARICATO, Ermínia. O “Minha Casa” é um avanço, mas segregação urbana fica intocada.Carta Maior, maio de 2009. Disponível em http://cartamaior.com.br. Acesso em: mar. 2010.

Portal Brasileiro de Dados Abertos. Indicadores sobre o Programa Minha Casa, Minha Vida. 2016.

RAMOS, J. da S.; NÓIA, A. C. Análise da execução do Programa Minha Casa Minha Vida nos municípios de Ilhéus e Itabuna, Bahia. Semana do Economista, 4., Encontro de Egressos, 4., Ilhéus, 2014. p. 1-20.

ROMAGNOLI, Alexandre J. O programa "minha casa, minha vida": continuidades, inovações e retrocessos. In: Temas de Administração Pública - TEMAP., São Paulo, v. 4, n. 7, pp. 1-29. 2012.

ROLNIK ET AL, Raquel. O Programa Minha Casa Minha Vida nas regiões metropolitanas de São Paulo e Campinas: aspectos socioespaciais e segregação. In: Cad. Metrop., São Paulo, v. 17, n. 33, pp. 127-154. 2015. 